\title{
The diversity of pteridophytes in Siberut National Park, Mentawai Islands, West Sumatra, Indonesia
}

\author{
MILDAWATI $^{1,2}$, SOBIR $^{3}$, SULISTIJORINI ${ }^{4}$, TATIK CHIKMAWATI ${ }^{4, \bullet}$ \\ ${ }^{1}$ Plant Biology Graduate Program, Department of Biology, Faculty of Mathematics and Natural Sciences, Institut Pertanian Bogor. Jl. Meranti, Kampus \\ Dramaga, Bogor 16680, West Java, Indonesia \\ ${ }^{2}$ Department of Biology, Faculty of Mathematics and Natural Sciences, Universitas Andalas. Jl. Raya Unand, Padang 25563, West Sumatra, Indonesia \\ ${ }^{3}$ Department of Agronomy and Horticulture, Faculty of Agriculture, Institut Pertanian Bogor. J1. Meranti, Kampus Dramaga, Bogor 16680, West Java, \\ Indonesia \\ ${ }^{4}$ Department of Biology, Faculty of Mathematics and Natural Sciences, Institut Pertanian Bogor. Jl. Agatis, Kampus Dramaga, Bogor 16680, West Java, \\ Indonesia. Tel./fax.: +62-251-8622833, ^email: tchikmawati@apps.ipb.ac.id
}

Manuscript received: 13 June 2020. Revision accepted: 21 June 2020.

\begin{abstract}
Mildawati, Sobir, Sulistijorini, Chikmawati T. 2020. The diversity of pteridophytes in Siberut National Park, Mentawai Islands, West Sumatra, Indonesia. Biodiversitas 21: 3200-3208. The diversity of Pteridophytes in the Siberut National Park (Siberut NP) Mentawai Islands, West Sumatra, is still very well preserved, but the information is limited. This research aimed to study the divesrity of Pteridophyte species in the Siberut NP in order to provide its taxonomic information using morphological data. The study consisted of exploration to collect plant specimens directly in the field, observation and identification of herbarium specimens in Herbarium Bogoriense and verification using online websites from various sources. A total of 69 species of Pteridophytes classified into 36 genera, and 20 families were recorded in the Siberut NP with Polypodiaceae has the most species diversity with 12 species of 6 genera. As many as 14 species are new records for Siberut Island, i.e. Selaginella involvens (Sw.) Spring (Selaginellaceae), Asplenium simile Blume (Aspleniaceae), Diplazium montanum V.A.V.R (Athyriaceae), Stenochlaena palustris (Burm) Bedd. (Gleichnaceae), Davallia solida (Forst.) Sw. (Davalliaceae), Callistopteris apiifolia (C.Presl) Copel., Crepidomanes humile Bosch (Hymenophyllaceae), Lindsaea carvifolia Kramer, Lindsaea doryphora Kramer, Lindsaea napaea Aldrew. (Lindsaeaceae), Nephrolepis biserrata (Sw.) Schott (Nephrolepidaceae), Ceratopteris thalictroides (L.) Brongn., Haplopteris ensiformis (Sw.) E.H.Crane and Syngramma alismifolia (Pr.) J.Sm. (Pteridaceae). The habitats of Pteridophytes found were mostly terrestrial and epiphytic (34 species each), while aquatic habitat was only found to one species. The results of this study will serve as baseline information of the plant diversity in the Siberut NP that can be used as a reference for future studies on Pteridophytes and to develop their conservation strategy in the region.
\end{abstract}

Keywords: Diversity, pteridophytes, Siberut, species

\section{INTRODUCTION}

Siberut National Park (Siberut NP) is located in the Mentawai Islands, West Sumatra Province, Indonesia. The islands are located off the western coast of Sumatra, Indonesia, and separated by the Indian Ocean from Sumatra Island with a distance between $85-135 \mathrm{~km}$ (Suparno 2013). The Mentawai Islands consist of four main islands, Siberut, Sipora, North Pagai, and South Pagai Islands with the largest island in this archipelago is Siberut Island. Siberut island has an area of $4,030 \mathrm{~km}^{2}$, and a part of the island is a conservation area known as the Siberut National Park (Siberut NP). The national park was established on October 8, 1993, with the government decree of Minister of Forestry, Indonesia through KepMenHut No. 407/Kpts-II/1993 with the total extent of 190.500 hectares in the center of Siberut Island. This area has a high diversity of plant and animal species, so protection efforts are needed to preserve it (Whittaker 2006).

Information on the diversity of plant and animal species in the Siberut NP is still very limited. Research that is quite intensive and has been widely publicized in this region is about the biological aspects of primate groups since there are endemic primates such as Macaca siberut (Richter et al. 2013). In contrast, study on flora diversity, especially Pteridophytes, still has a great opportunity to expose new information in this area.

Pteridophytes are vascular plants that grow abundantly in tropical and temperate forests (Dixit 2000). About 13,600 species of pteridophytes are known to have geographic distribution all over the world, and they constitute a primitive group of vascular plants (Watkins et al. 2006). Pteridophytes can be found in various habitats from terrestrial, epiphytic to aquatic habitat across broad range of ecosystems from high montane forests to coastal ecosystems.

Pteridophytes have microphylls (small leaves) or megaphylls (large leaves) called fronds. Pteridophytes with megaphylls are characterized by having the main stem of pteridophytes call rhizome. The rhizome may lie on the surface of a substrate (creeping), or be erect and sometimes forming a trunk. The structure of the rhizome and the shape of vascular system characters can be used for identification and classification of Pteridophytes. Fronds (petiole and lamina) grow from the rhizomes, and emerge as fiddleheads (circinate coiled). The characteristics of petiole or stipe of a particular number of pteridophytes are very 
important morphological characters in the identification and classification of Pteridophytes. In the past, classification often used sterile leaves, simple or highly divided leaves, but the leaf division was used for classification species rank. Spore-producing sporangia, which are typically organized in groups, are called sori and found in the fertile leaves. Sporangia and sori for some groups of Pteridophytes have specialized structures. An interpretation of a few extrinsic characters generally shows a trend of Pteridophytes classification. The placement of many genera as trends of classification concepts using molecular phylogenetics nowadays have rapidly been improving our understanding of pteridophyte classification (Christenhusz and Chase 2014).

In the context of Siberut NP, the limited research on Pteridophytes compared to other studies is likely due to the limited understanding of the potential uses of these plants as well as directly and related to the lack of awareness in environmental conservation of the national park. As such, inventory of pteridophytes in this area is needed to reveal their diversity as a starting point to explore their potential uses as well as to preserve the ecosystem. One of the studies on Pteridophytes in the Mentawai Islands that has been published was the distribution of Tectaria kehdingiana (Kuhn) M.G. Price (Tectariaceae) that is endemic species of Pteridophyte in the Sipora island (Wongphakdee et al. 2016), which is the group of the Mentawai island, but there is no complete taxonomic information on the diversity of fern species found in other islands in the Mentawai Islands including the Siberut NP region. One of the publications found today about species of Pteridophytes in the Mentawai region is a book titled "Spolia Mentawiensia: Pteridophyta" compiled by Holttum in 1928 which only displays a checklist of species name according to the nomenclature of that year.

Research on the diversity of Pteridophytes in Siberut NP is important and will serve as baseline information of the plant diversity in the Siberut NP. This research aimed to study the diversity of Pteridophyte species in the Siberut $\mathrm{NP}$ in order to provide its taxonomic information using morphological data. The benefit of this study was to provide data and information that can be used as a reference for future studies on Pteridophytes and to develop their conservation strategy in the region.

\section{MATERIALS AND METHODS}

\section{Study period and area}

The study consisted of exploration to collect plant specimens directly in the field, observation and identification of herbarium specimens and verification using online websites from various sources. Field exploration was carried out from 26 June to 2 July 2019. Specimens were collected from the core zone area of the Siberut National Park (Figure 1). Coordinate sample collection in the field is from $01^{\circ} 09^{\prime} 14.8^{\prime \prime} \mathrm{N} 98^{\circ} 57^{\prime} 17.6^{\prime \prime} \mathrm{E}$ in Muara Sikabaluan to $01^{\circ} 12^{\prime} 13.6^{\prime \prime} \mathrm{N} 98^{\circ} 49^{\prime} 57.03^{\prime \prime} \mathrm{E}$ in
Bekemen Bojakan Village. The location of this study was reached by boat through the river about 5 hours from the national park office in Muara Sikabaluan, North Siberut.

\section{Collection procedures}

All samples of Pteridophytes were collected from rhizomes, stems, sterile, and fertile lamina. The coordinate points were recorded using GPS Garmin eTrex 10, while temperature, humidity, wind speed, and light intensity were measured using Anemometer Digital Lutron LM 80004 in 1. Preparation of Pteridophytes specimens for deposit in Herbarium base on Rugayah et al. (2004)

\section{Specimen identification}

Identification of Pteridophytes was carried out using a morphological approach by observing the characteristics found in rhizomes, stipe, sterile, and fertile lamina, the shape of the sorus, and habitat for growing. Identification of Pteridophytes was done by referring several reference books including Spolia Mentawiensia (Holttum R.E 1928); Flora Malesiana revisions (Holttum 1963, Nooteboom 1998; Nooteboom et al. 2012), Fern Flora of Thailand, Laos, and Cambodia (Lindsay and Middleton 2012), and Pteridophytes of Solomon (Chen et al. 2017) and internet search using Global online sites Biodiversity Information Facility (GBIF) (https: //www.gbif.org/).

Besides observing and identifying specimens collected from the field in the context of this study, we also conducted observation and identification of herbarium specimens of Pteridophytes collected from previous expeditions in Siberut NP which are stored in the Herbarium Bogoriense, Center for Biological Research, Cibinong, Indonesia to provide comprehensive information about the diversity of Pteridophytes in the region.

The conservation status of fern species found in the Siberut National Park was checked using the International Union for Conservation of Nature and Natural Resources (IUCN) Red List online site version 2019-3. Based on the site, there are several criteria for the conservation status of plants including Extinct (EX); Extinct in the Wild (EW); Critically Endangered (CR), Endangered (EN), Vulnerable (VU), Near Threatened (NT), Least Concern (LC), Data Deficient (DD), and Not Evaluated (NE) (IUCN 2019).

\section{RESULTS AND DISCUSSION}

\section{Results}

As many as 18 specimen numbers were collected directly from the field, three specimens were observed based on information obtained from the GBIF website, and 75 sheets were specimens from the Herbarium Bogoriense (BO) collections. In total, there were 96 sheets of specimens observed and identified. All specimens observed were verified by using specimen type from Herbarium Bogoriense and the JSTOR site accessed using IPB University 2019 network on January 3, 2020. 


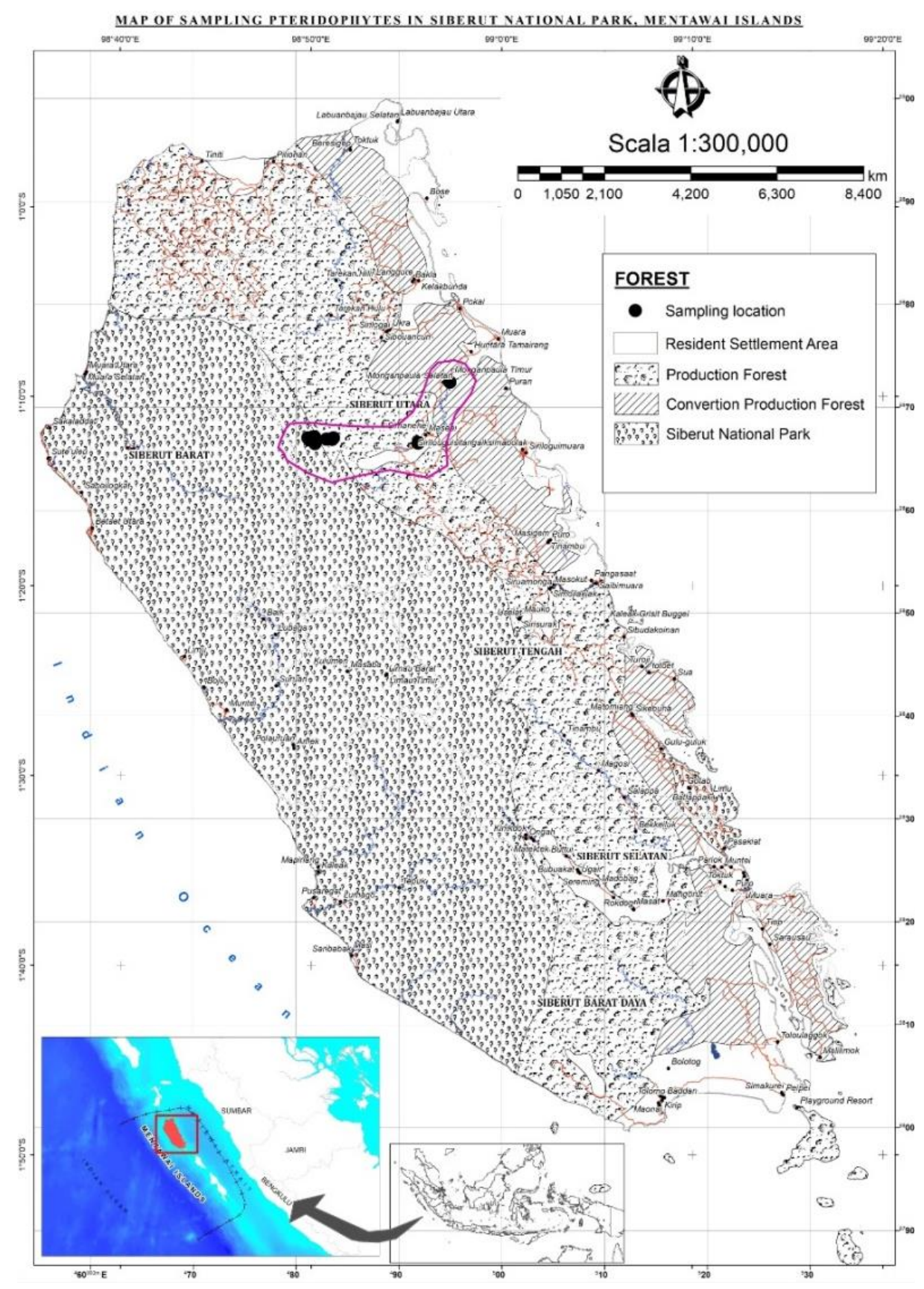

Figure 1. Map of sampling locations in Siberut National Park, West Sumatra, Indonesia

We found Pteridophytes species in the Siberut NP consists of 69 species, 36 genera, and 20 families (Table 1). Among them, 14 species are new records for the Siberut NP belong to 12 genera and ten families. The new records are Selaginella involvens (Sw.) Spring (Selaginellaceae), Asplenium simile Blume (Aspleniaceae), Diplazium pallidum (Blume) T.Moore (Athyriaceae), Stenochlaena palustris (Burm) Bedd. (Blechnaceae), Davallia solida (Forst.) Sw. (Davalliaceae), Callistopteris apiifolia (C.Presl) Copel., Crepidomanes humile Bosch (Hymenophyllaceae), Lindsaea carvifolia Kramer, Lindsaea doryphora Kramer, Lindsaea napaea Aldrew. (Lindsaeaceae), Nephrolepis biserrata (Sw.) Schott (Nephrolepidaceae), Ceratopteris thalictroides (L.)
Brongn., Haplopteris ensiformis (Sw.) E.H.Crane and Syngramma alismifolia (Pr.) J.Sm. (Pteridaceae).

The composition of the genera and species number for each family found in this region is presented in Table 1. The highest number of species found is Polypodiaceae (Figure 2). This family consists of 12 species, including six genera dominated by Pyrrosia with four species and Phymatosorus with three species. Previous studies mentioned that Polypodiaceae is a family with the highest number of genera in Pteridophytes, consisting of 50 genera and 1,200 species (Smith et al. 2006). Families with a small number of species (1 species) are 5 families, including Athyriaceae, Gleicheniaceae, Schizaeaceae, Marattiaceae, and Tectariaceae. 
Table 1. List of species of pteridophytes and its habitat in the Siberut National Park, Mentawai Islands, West Sumatra, Indonesia

\begin{tabular}{|c|c|c|c|c|}
\hline Family & Genus & $\begin{array}{l}\text { No of } \\
\text { species in } \\
\text { the genus }\end{array}$ & Species name & Habitat \\
\hline \multirow[t]{5}{*}{ Lycopodiaceae } & Phlegmariurus & 4 & Phlegmariurus phlegmaria (L.) Holub & E \\
\hline & & & Phlegmariurus cancellatus (Spring) Ching & $\mathrm{E}$ \\
\hline & & & Phlegmariurus nummulariifolius (B1.) Ching & $\mathrm{E}$ \\
\hline & & & Phlegmariurus squarrosus (G.Forst.) A.Löve \& D.Löve & $\mathrm{E}$ \\
\hline & Palhinhaea & 1 & Palhinhaea cernua (L.) Vasc. \& Franco & $\mathrm{T}$ \\
\hline \multirow[t]{2}{*}{ Selaginellaceae } & Selaginella & 2 & Selaginella involvens (Sw.) Spring** & $\mathrm{T}$ \\
\hline & & & Selaginella kittyae Aldrew.*** & $\mathrm{T}$ \\
\hline \multirow[t]{6}{*}{ Aspleniaceae } & Asplenium & 6 & Asplenium simile Blume** & $\mathrm{E}$ \\
\hline & & & Asplenium phyllitidis D.Don & $\mathrm{E}$ \\
\hline & & & Asplenium paradoxum $\mathrm{Bl}$. & $\mathrm{E}$ \\
\hline & & & Asplenium pellucidum Lam. & $\mathrm{E}$ \\
\hline & & & Asplenium tenerum G.Forst. & $\mathrm{E}$ \\
\hline & & & Asplenium thunbergii Kunze & E \\
\hline Athyriaceae & Diplazium & 1 & Diplazium pallidum (Blume) T.Moore* & $\mathrm{T}$ \\
\hline \multirow[t]{2}{*}{ Blechnaceae } & Blechnum & 1 & Blechnopsis finlaysoniana C.Presl & $\mathrm{T}$ \\
\hline & Stenochlaena & 1 & Stenochlaena palustris (Burm.) Bedd.** & $\mathrm{T}$ \\
\hline \multirow[t]{2}{*}{ Cyatheaceae } & Alsophila & 2 & Sphaeropteris parvifolia (Holtt.) R.M.Tryon & $\mathrm{T}$ \\
\hline & & & Alsophila alderwereltii (Copel.) R.M.Tryon & $\mathrm{T}$ \\
\hline \multirow[t]{2}{*}{ Davalliaceae } & Davallia & 2 & Davallia repens Kuhn & E \\
\hline & & & Davallia solida (Forst.) Sw.** & E \\
\hline \multirow[t]{2}{*}{ Dryopteridaceae } & Bolbitis & 1 & Bolbitis sinuata (C.Presl) Hennipman & $\mathrm{E}$ \\
\hline & Pleocnemia & 1 & Pleocnemia irregularis (C. Presl) Holttum. & $\mathrm{T}$ \\
\hline Gleicheniaceae & Sticherus & 1 & Sticherus truncatus (Willd.) Nakai & $\mathrm{T}$ \\
\hline \multirow[t]{7}{*}{ Hymenophyllaceae } & Callistopteris & 1 & Callistopteris apiifolia (Presl) Copel. ** & $\mathrm{T}$ \\
\hline & Cephalomanes & 1 & Cephalomanes javanicum C.Presl** & E \\
\hline & Crepidomanes & 4 & Crepidomanes aphlebioides (Christ) I.M.Turner & $\mathrm{E}$ \\
\hline & & & Crepidomanes bilabiatum (Nees \& Blume) Copel. & E \\
\hline & & & Crepidomanes humile Bosch ** & $\mathrm{E}$ \\
\hline & & & Vandenboschia maximum (Blume) Copel. & E \\
\hline & Trichomanes & 1 & Trichomanes cupressoides Desv. & E \\
\hline \multirow{5}{*}{ Lindsaeaceae } & Lindsaea & 5 & Lindsaea carvifolia Kramer ** & E \\
\hline & & & Lindsaea doryphora Kramer*** & $\mathrm{T}$ \\
\hline & & & Lindsaea napaea Aldrew.*** & $\mathrm{T}$ \\
\hline & & & Lindsaea cultrata (Willd.) Sw. & $\mathrm{E}$ \\
\hline & & & Lindsaea pectinata Blume & $\mathrm{E}$ \\
\hline \multirow[t]{2}{*}{ Lygodiaceae } & Lygodium & 2 & Lygodium borneense Alderw. & $\mathrm{T}$ \\
\hline & & & Lygodium circinnatum Sw. & $\mathrm{T}$ \\
\hline Marattiaceae & Christensenia & 1 & Christensenia aesculifolia (B1.) Maxon & $\mathrm{T}$ \\
\hline \multirow[t]{2}{*}{ Nephrolepidaceae } & Nephrolepis & 2 & Nephrolepis exaltata (L.) Schott & $\mathrm{T}$ \\
\hline & & & Nephrolepis biserrata (Sw.) Schott ** & $\mathrm{E}$ \\
\hline \multirow[t]{2}{*}{ Ophioglossaceae } & Helminthostac-hys & 1 & Helminthostachys zeylanica (L.) Hook. & $\mathrm{T}$ \\
\hline & Ophioglossum & 1 & Ophioderma pendulum (L.) C.Presl & E \\
\hline Polypodiaceae & Lecanopteris & 1 & Lecanopteris sinuosa Copel. & E \\
\hline & Lepisorus & 2 & Lepisorus longifolius (Blume) Holttum & E \\
\hline & & & Lepisorus spicatus (L.fil.) Li Wang & $\mathrm{E}$ \\
\hline & Microsorum & 1 & Microsorum heterocarpum Ching & $\mathrm{T}$ \\
\hline & Phymatosorus & 3 & Phymatosorus longissimus (Blume) Pic.Serm. & $\mathrm{T}$ \\
\hline & & & Phymatosorus membranifolius (R.Br.) S.G. Lu. & $\mathrm{T}$ \\
\hline & & & Phymatosorus scolopendria Pic. Serm. & $\mathrm{T}$ \\
\hline & Pyrrosia & 4 & Pyrrosia angustata (Sw.) Ching & E \\
\hline & & & Pyrrosia lanceolata Farw. & E \\
\hline & & & Pyrrosia longifolia (Burm.f.) Morton & E \\
\hline & & & Pyrrosia nummularifolia (Sw.) Ching & $\mathrm{E}$ \\
\hline & Selliguea & 1 & Selliguea enervis (Cav.) Ching** & $\mathrm{E}$ \\
\hline Pteridaceae & Ceratopteris & 1 & Ceratopteris thalictroides (L.) Brongn.* & A \\
\hline & Haplopteris & 2 & Haplopteris ensiformis (Sw.) E.H.Crane** & E \\
\hline & Pteris & 3 & $\begin{array}{l}\text { Haplopteris scolopendrina C.Presl } \\
\text { Pteris longininnula Wall }\end{array}$ & $\begin{array}{l}\mathrm{E} \\
\mathrm{T}\end{array}$ \\
\hline & & & Pteris tripartita $\mathrm{Sw}$. & $\mathrm{T}$ \\
\hline & & & Pteris wallichiana C.Agardh** & $\mathrm{T}$ \\
\hline & Syngramma & 1 & Syngramma alismifolia (Pr.) J.Sm.* & $\mathrm{T}$ \\
\hline & Taenitis & 1 & Taenitis blechnoides (Willd.) Sw.** & $\mathrm{T}$ \\
\hline Schizaeaceae & Schizaea & 1 & Schizaea dichotoma (L.) Sm. & $\mathrm{T}$ \\
\hline Tectariaceae & Tectaria & 1 & Tectaria aspidioides Copel. & $\mathrm{T}$ \\
\hline Thelypteridaceae & Pneumatopteris & 1 & Pneumatopteris truncata (Poir.) Holttum & $\mathrm{T}$ \\
\hline & Pronephrium & 2 & Pronephrium glandulosum (Blume) Holttum & $\mathrm{T}$ \\
\hline & & & Pronephrium repandum (Fée) Holttum** & $\mathrm{T}$ \\
\hline & Sphaerostephanos & 2 & Sphaerostephanos heterocarpus (Blume) Holttum & $\mathrm{T}$ \\
\hline & & & Sphaerostephanos latebrosus (Kunze ex Mett.) Holttum & $\mathrm{T}$ \\
\hline
\end{tabular}




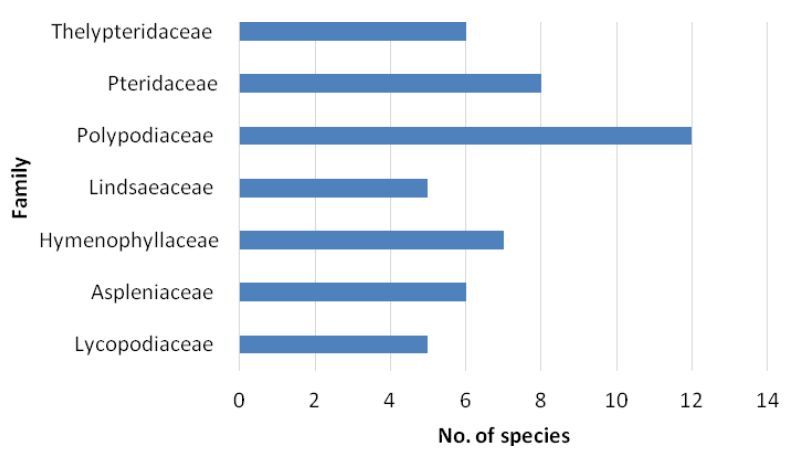

Figure 2. The number of Pteridophytes species dominates in Siberut National Park, Mentawai Islands, West Sumatra, Indonesia

Besides Polypodiaceae, the diversity of genera is also found in several families, including the Hymenophyllaceae, which consists of 4 genera, among the 9 genera described in the world, Callistopteris, Cephalomanes Crepidomanes and Trichomanes (Ebihara et al. 2006). Thelypteridaceae is composed of 3 genera, among 32 genera described in the world, including Pneumatopteris, Pronephrium, and Sphaerostephanos (Schuettpelz et al. 2016), Pteridaceae consists of 5 genera including Ceratopteris, Haplopteris, Pteris, Syngramma and Taenitis from 53 genera spread in tropical and subtropical regions (Schuettpelz et al. 2016). This result shows that the four families also have high diversity at the level of species and genera of Pteridophytes in the Siberut NP area (Figure 2).

Pteridophytes found in the Siberut NP grow in three habitats: terrestrial, epiphytic, and aquatic. Terrestrial and epiphyte Pteridophytes were found with the same number of species, i.e. 34 species $(49.0 \%)$, while aquatic Pteridophytes found only one species $(2.0 \%)$ (Table 1, Figure 3). Specific diversity of species is found in humid areas with more open canopies, such as trees on the left or right side of a river. In the Mentawai Islands, the river is the main access as a means of transportation for the community so that this area is widely used by the community as a plantation, farming, and livestock areas. Thus epiphytic Pteridophytes are found in plantation areas while terrestrial Pteridophytes are found on the banks of rivers in the core zone of the Siberut NP forest area.

Compared to other islands, the diversity of Pteridophytes species in the Siberut NP is much higher than in Enggano Island (Wardani and Adjie 2017). There is a similarity in the composition of Pteridophytes species $(32.14 \%)$ and genera $(46.70 \%)$ between the two islands (Figure 4). The similarity species of both islands are Phlegmariurus phlegmaria (L.) Holub, Phlegmariurus cancellatus (Spring) Ching, Phlegmariurus nummulariifolius (Blume) Ching, Phlegmariurus squarrosus (G.Forst.) Á.Love \& D.Love, Palhinhaea cernua (L.) Vasc. \& Franco (Lycopodiaceae), Asplenium tenerum G.Forst. (Aspleniaceae), Stenochlaena palustris (Burm) Bedd. (Blechnaceae), Davallia repens Kuhn,

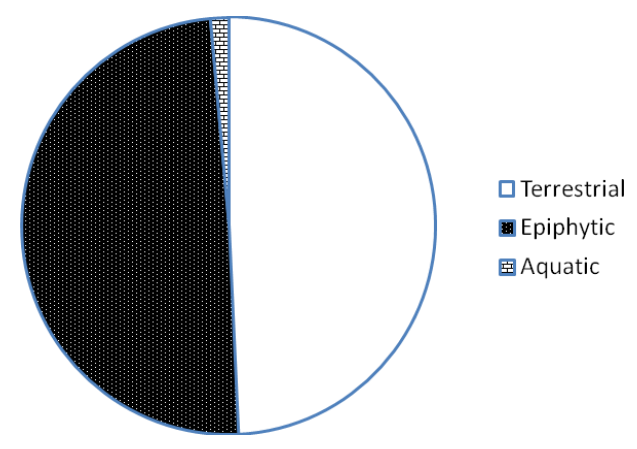

Figure 3. Habitat of Pteridophytes in Siberut National Park, Mentawai Islands, West Sumatra, Indonesia

Davallia solida (Forst.) Sw. (Davalliaceae), Pleocnemia irregularis (C. Presl) Holttum (Dryopteridaceae), Sticherus truncatus (Willd.) Nakai (Gleicheniaceae), Cephalomanes javanicum C.Presl (Hymenophyllaceae), Lygodium circinnatum Sw. (Lygodiaceae), Pyrrosia lanceolata (L.) Farw (Polypodiaceae), Ceratopteris thalictroides (L.) Brongn., Pteris wallichiana C.Agardh, Taenitis blechnoides (Willd.) Sw (Pteridaceae) dan Pronephrium glandulosum (Blume) Holttum (Thelypteridaceae). On the other hand, there are 52 species belong to 23 genera and nine families of Pteridophytes found in the Siberut NP which was not found in Enggano Island. The nine families include Selaginellaceae, Athyriaceae, Cyatheaceae, Dryopteridaceae, Lindsaeaceae, Nephrolepidaceae, Ophioglossaceae, Schizaeaceae, and Tectariaceae.

The high diversity of Pteridophytes in the Siberut NP is supported by conditions of biotic and abiotic factors in the area. The national park area has an extent of around 403,000 hectares (ha) in total, consisting of oceans and land areas. The core zone is 190,500 ha while the buffer zone is around 128,277 ha, and the transition area is 84,223 ha. The daily average temperature is around $30.6^{\circ} \mathrm{C}$ $\left(25.6^{\circ} \mathrm{C}\right.$ in a forest area and $37.5^{\circ} \mathrm{C}$ near the coast). Humidity in this region ranges from $65.2 \%$ to $89.1 \%$ with altitude from 0-183 meters above sea level (masl). Abiotic conditions such as humidity, texture, $\mathrm{pH}$ and soil nutrition, air humidity, light intensity, precipitation, altitude, topography, and temperature in the atmosphere are directly correlated with the presence, abundance, frequency, and diversity of Pteridophytes. A well-maintained habitat will have a wealth of species and an abundance of pteridophytes (Della and Falkenberg 2019).

Based on IUCN Red List data, Pteridophytes found in this study were categorized into two groups: Least Concern (LC; Low Risk) and Not Evaluated (NE; Not evaluated or data not found) categories. Crepidomanes maximum (Blume) K. Iwats (Hymenophyllaceae) and Ceratopteris thalictroides (L.) Brongn. (Pteridaceae) are in the category of Least Concern (LC; Low Risk) while the other 67 species are included as Not Evaluated (NE; Not evaluated or data not found). 


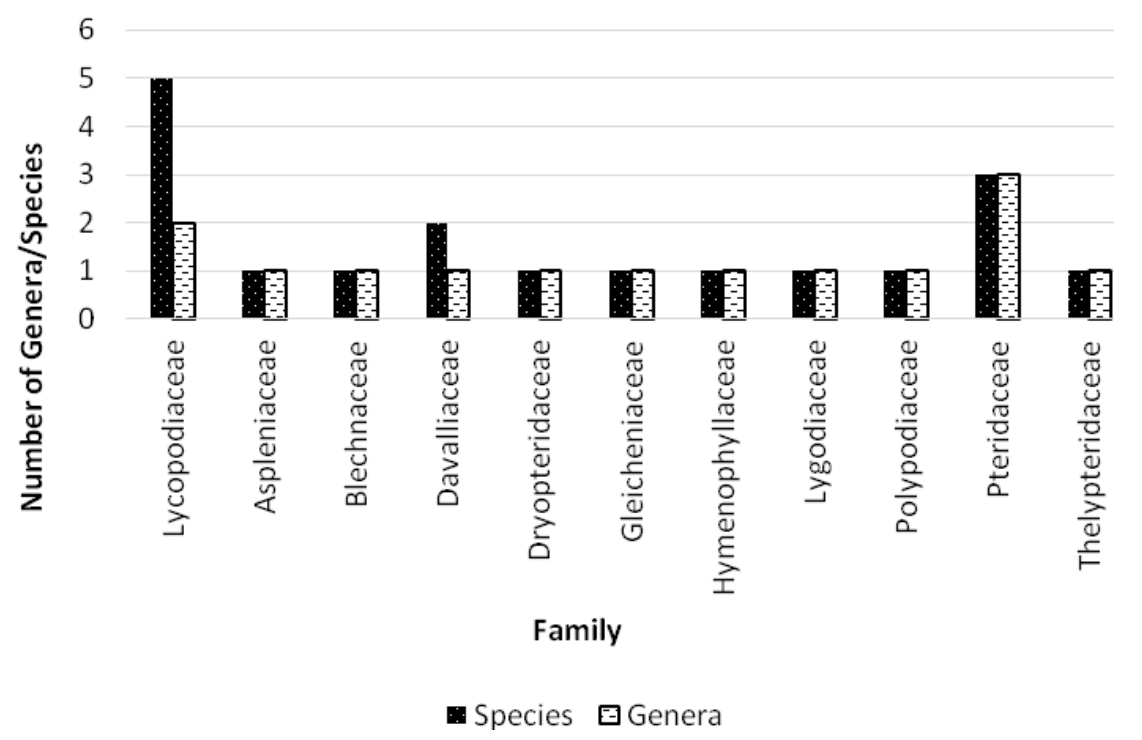

Figure 4. The similarity of the number of genera and species of pteridophytes in found in Siberut Siberut National Park, Mentawai Islands, West Sumatra, Indonesia and pteridophytes of Enggano Island, Bengkulu, Indonesia (Wardani and Adji 2017)

\section{Discussion}

Our study is the first report that reveals the diversity of Pteridophytes in the Siberut NP. We found 69 species, 36 genera, and 20 families. Based on Pteridophyte Phylogeny Group I (PPG I) (2016), Pteridophytes in the world consist of 11.916 species belonging to 337 genera, 51 families, 14 orders, and two classes. The diversity of Pteridophytes in the Siberut National Park conservation area is quite high because at least $42 \%$ of the families of Pteridophytes in the world are found in this region. This likely because the condition of forest areas in the Siberut NP is still relatively natural as a habitat for a variety of plant species (Hadi et al. 2009).

Based on previous studies on the distribution of Pteridophytes, there are some species we found in this study but they have not been reported to have geographical distribution on the island of Sumatra. Among these species are Phlegmariurus cancellatus (Spring) Ching, Selaginella involvens ( $\mathrm{Sw}$.) Spring, Crepidomanes bilabiatum (Nees \& Blume) Copel, Trichomanes cupressoides Desv, Lindsaea carvifolia Kramer, Nephrolepis exaltata (L.) Schott, Pyrrosia nummulariifolia (Sw.) Ching, Pteris longipinnula Wall, Tectaria aspidioides Copel, Sphaerostephanos latebrosus (Kunze ex Mett.) Holttum and Pteris wallichiana C.Agardh. The last species mentioned is rarely found in the Malesia region because it is generally distributed in the European region. This species is also informed as a new record for Pteridophytes on Mount Slamet, Java Island, at an altitude of $1390-1450 \mathrm{~m}$ asl (Praptosuwiryo 2013).

Some of these species are also new records for Siberut Island as we found new record of 14 species of Pteridophytes in the Siberut NP. One of them is Selaginella involvens (Sw.) S. Spring. During exploration, this species was found dominating at the floor of the Siberut NP forest.
This species is used as ingredients of traditional medicines for the human community in China and India (Setyawan 2011). Asplenium simile Blume has wide distribution and habitat in Malesia, including in rocky areas such as limestone in Kelantan, Malaysia (Kiew et al. 2019). Diplazium pallidum (Blume) T.More, which belongs to the family Athyriaceae, still has nomenclature problems so that currently, the use of leaf architects is reported as a feature to distinguish between species in these genera (Conda et al. 2017). Stenochlaena palustris (Burm) Bedd. is widespread in the lowlands. The exploration conducted on the island of Siberut, starting from Muara Sikabaluan, found this species abundantly in the areas that had experienced land clearing. Siberut Island has the characteristics of lowland overgrown by mangrove forests. The trees in the mangrove forest area covered by the species Stenochlaena palustris (Burm) Bedd. This species is a hemiepiphyte plant that lives on the edge of a forest with relatively high light conditions on moist soil or aquatic environments (Chambers 2013). Davallia solida (Forst.) Sw. has a wide distribution in Malesia and Polynesia. This species is also abundant in this area that lives epiphytically on Areca catechu Linn. (Arecaceae) along the river from Muara Sikabaluan to the upstream area with a distance of about $7 \mathrm{~km}$ until the core zone of the Siberut NP in Bojakan Village. Another new record for the Siberut NP, Callistopteris apiifolia (Presl) Copel., found on habitat of the moist mountain slopes. Based on the morphological character, this species has high similarity of morphological characters of tripinnate pinna to Callistopteris superba (Backh) Ebihara \& K.Iwats (Popelka et al. 2018).

Crepidomanes humile Bosch is dominant in the riverside of the Siberut NP. This species, that has terrestrial or epiphytic habitat has long-creeping or erect rhizomes, an indumentum of hairs, membranous, and often translucent 
laminae, marginal sori, tubular or bivalvate indusia, extended receptacles, sporangia with an oblique annulus, and trilete, green spores. Hymenophyllaceae has its greatest diversity in tropical and south temperate regions and Malesia (Taiwan, Thailand, Malaysia, Philippines, Indonesia, Papua New Guinea, Australia (Queensland), Micronesia, Solomon Islands, New Caledonia, Vanuatu, Fiji, Samoa, Tonga, Austral Islands) (Brownsey and Perrie 2016). On the other hand, Lindsaea carvifolia Kramer, Lindsaea doryphora Kramer, and Lindsaea napaea Aldrew. are three species found as new records from a total of five species of Lindsaea found in this region. Some species as new records in the Siberut NP, such as five species of Lindsaea, Haplopteris ensiformis (Sw.) E.H.Crane and Syngramma alismifolia (Pr.) J.Sm., has a wide distribution in the national park because the natural habitat is still reserved for a conservation area in Malesia and the Pantropical region (Dong et al. 2016; Lindsay and Middleton 2015; Hidayat et al. 2011).

Some Pteridophytes in the Siberut NP are used by local community in Siberut for medicinal purposes. These species are Nephrolepis biserrata (Sw.) Schott and Ceratopteris thalictroides (L.) Brongn. that are widely used by the community as a medicinal ingredient because of its high antioxidant content (Golan et al. 2013; Joshi et al. 2019).

The natural habitats of the Pteridophytes found in the Siberut NP area were terrestrial, epiphytic, and aquatic. Plants that have terrestrial habitat were found in several families, namely Selaginellaceae, Athyriaceae, Blechnaceae, Cyatheaceae, Gleicheniaceae, Lygodiaceae, Marattiaceae, Nephrolepidaceae, Schizaeaceae, Tectariaceae, and Thelypteridaceae. Terrestrial plants have a large diameter, dry weight, length, volume, and density of lamina and petiole (Creese et al. 2011). This pattern is related to the ability of this plant to capture the intensity of light and carbon in damp places to balance environmental pressures (Niinemets et al. 2007). The plants that have epiphytic habitat were found in three families, namely Lycopodiaceae, Aspleniaceae, and Davalliaceae. Besides that, there were also species of Pteridophytes that have two habitats: terrestrial and epiphytes, in a family, namely Dryopteridaceae, Hymenophyllaceae except for species Callistopteris apiifolia (Presl) Copel. which lives terrestrial, Ophioglossaceae, Lindsaeaceae, and Polypodiaceae. Species that found in all three habitats is from the family of Pteridaceae. In this family, there are one species that lived in aquatic habitat namely Ceratopteris thalictroides (L.) Brongn. This species can grow in the lowlands to an altitude of $1300 \mathrm{~m}$ asl. Generally, it is found in waters at an altitude of 500 meters asl. This species is used as medicine and vegetables by the community (Joshi et al. 2019).

Using different lists of conservation status assessments (i.e. Chandra et al. (2008) and Fraser-Jenkins (2012)), in total there are 27 species from 20 genera and 13 families found in Siberut NP with conservation concern (Table 2).

Referring to Chandra et al. (2008), there are 14 species of Pteridophytes in the Siberut NP that have At Risk status including Asplenium pellucidum Lam, Asplenium thunbergii Kunze, Blechnum finlaysonianum Wall, Bolbitis sinuata (C.Presl) Hennipman, Callistopteris apiifolia (C.Presl) Copel., Cephalomanes javanicum C.Presl, Crepidomanes maximum (Blume) K. Iwats, Lygodium circinnatum Sw., Helminthostachys zeylanica (L.) Hk, Ophioglossum pendulum L, Pteris tripartita Sw, Syngramma alismifolia (Pr.) J.Sm., Taenitis blechnoides (Willd.) Sw and Schizaea dichotoma (L.) Sm. In addition, there are two species threatened with extinction (Near Threatened) status, namely Crepidomanes humile Bosch and Sphaerostephanos heterocarpus (Blume) Holttum. Meanwhile, Phlegmariurus phlegmaria (L.) Holub, Crepidomanes bilabiatum (Nees \& Blume) Copel and Pyrrosia nummulariifolia (Sw.) Ching are included in the Rare (R) category.

Table 2. Table of comparison of category status of fern plant conservation in Siberut National Park, Mentawai Islands, West Sumatra, Indonesia

\begin{tabular}{|c|c|c|}
\hline Families/species & $\begin{array}{c}\text { Chandra } \\
\text { (2008) }\end{array}$ & $\begin{array}{c}\text { F-Jenkins } \\
\text { (2010) }\end{array}$ \\
\hline \multicolumn{3}{|l|}{ Lycopodiaceae } \\
\hline Phlegmariurus phlegmaria (L.) Holub & $\mathrm{R}$ & $\mathrm{NE}$ \\
\hline \multicolumn{3}{|l|}{ Aspleniaceae } \\
\hline Asplenium simile Blume & $\mathrm{NE}$ & NT \\
\hline Asplenium pellucidum Lam & $\mathrm{AR}$ & CR \\
\hline Asplenium tenerum G.Forst. & NE & NT \\
\hline Asplenium thunbergii Kunze & $\mathrm{AR}$ & $\mathrm{CR} / \mathrm{EW}$ \\
\hline \multicolumn{3}{|l|}{ Blechnaceae } \\
\hline Blechnopsis finlaysoniana C.Presl & $\mathrm{AR}$ & VU \\
\hline \multicolumn{3}{|l|}{ Davalliaceae } \\
\hline Davallia repens Kuhn & $\mathrm{NE}$ & VU \\
\hline Davallia solida (Forst.) Sw. & $\mathrm{NE}$ & EN \\
\hline \multicolumn{3}{|l|}{ Dryopteridaceae } \\
\hline Bolbitis sinuata (C.Presl) Hennipman & $\mathrm{AR}$ & EN \\
\hline \multicolumn{3}{|l|}{ Hymenophyllaceae } \\
\hline Callistopteris apiifolia (Presl) Copel. & $\mathrm{AR}$ & CR \\
\hline Cephalomanes javanicum C.Presl & $\mathrm{AR}$ & $\mathrm{NE}$ \\
\hline $\begin{array}{l}\text { Crepidomanes bilabiatum (Nees \& B1.) } \\
\text { Copel. }\end{array}$ & $\mathrm{R}$ & $\mathrm{NE}$ \\
\hline Crepidomanes humile Bosch & NT & $\mathrm{NE}$ \\
\hline Vandenboschia maximum (B1.) Copel. & $\mathrm{AR}$ & $\mathrm{EN}$ \\
\hline \multicolumn{3}{|l|}{ Lygodiaceae } \\
\hline Lygodium circinnatum $\mathrm{Sw}$. & $\mathrm{AR}$ & $\mathrm{NE}$ \\
\hline \multicolumn{3}{|l|}{ Marattiaceae } \\
\hline Christensenia aesculifolia (B1.) Maxon & $\mathrm{NE}$ & $\mathrm{EN}$ \\
\hline \multicolumn{3}{|l|}{ Ophioglossaceae } \\
\hline Helminthostachys zeylanica (L.) Hk. & $\mathrm{AR}$ & $\mathrm{NE}$ \\
\hline Ophioglossum pendulum $\mathrm{L}$. & $\mathrm{AR}$ & NT \\
\hline \multicolumn{3}{|l|}{ Polypodiaceae } \\
\hline Phymatosorus longissimus (Bl.) Pic. Serm. & $\mathrm{NE}$ & VU \\
\hline Pyrrosia longifolia (Burm. f.) Morton. & $\mathrm{NE}$ & EN \\
\hline Pyrrosia nummulariifolia (Sw.) Ching & $\mathrm{R}$ & $\mathrm{NE}$ \\
\hline \multicolumn{3}{|l|}{ Pteridaceae } \\
\hline Haplopteris ensiformis (Sw.) E.H.Crane & $\mathrm{R}$ & $\mathrm{NE}$ \\
\hline Pteris tripartita $\mathrm{Sw}$. & $\mathrm{AR}$ & EN \\
\hline Syngramma alismifolia (Pr.) J.Sm. & $\mathrm{AR}$ & $\mathrm{NE}$ \\
\hline Taenitis blechnoides (Willd.) & $\mathrm{AR}$ & EN \\
\hline \multicolumn{3}{|l|}{ Schizaeaceae } \\
\hline Schizaea dichotoma (L.) Sm. & $\mathrm{AR}$ & VU \\
\hline \multicolumn{3}{|l|}{ Thelypteridaceae } \\
\hline Sphaerostephanos heterocarpus (Bl.) Holtt. & NT & $\mathrm{NE}$ \\
\hline
\end{tabular}


Referring to Fraser-Jenkins (2012), three species have Critically Endangered (CR) status, including Asplenium pellucidum Lam, Asplenium thunbergii Kunze, and Callistopteris apiifolia (C.Presl) Copel. Seven species have Endangered (EN) status, including Davallia solida (Forst.) Sw, Bolbitis sinuata (C.Presl) Hennipman, Crepidomanes maximum (Blume) K. Iwats, Christensenia aesculifolia (B1.) Maxon, Pyrrosia longifolia (Burm. f.) Morton, Pteris tripartita $\mathrm{Sw}$ dan Taenitis blechnoides (Willd.) Sw. Four species have Vulnerable (VU) status including Blechnum finlaysonianum Wall, Davallia repens Kuhn, Phymatosorus longissimus (Blume) Pic. Serm. and Schizaea dichotoma (L.) Sm and three species have Near Threatened (NT) status, including Asplenium simile Blume, Asplenium tenerum G.Forst. and Ophioglossum pendulum L.

Based on Chandra et al. (2008) and Fraser-Jenkins (2012), some species of Pteridophytes in the Siberut NP such as Asplenium pellucidum Lam, Asplenium thunbergii Kunze, and Callistopteris apiifolia (C.Presl) Copel. need more intensive priority of conservation since they have AtRisk and Critically Endangered categories.

This research is very important in providing basic information about the diversity of Pteridophytes in the Siberut NP. The diversity of Pteridophytes is also related to the role of these plants as pioneer plants. In addition, Pteridophytes also act as providers of oxygen, water absorbers, small animal habitats, environmental indicators, and maintain the humidity and balance of the forest ecosystem, such as preventing erosion, regulating water content, and helping the weathering process of forest litter (Della and Falkenberg 2019).

In conclusion, a total of 69 species of Pteridophytes belonging to 36 genera and 20 families were recorded in the Siberut NP with Polypodiaceae has the most species diversity. As many as 14 species are new records for Siberut Island, i.e. Selaginella involvens (Sw.) Spring (Selaginellaceae), Asplenium simile Blume (Aspleniaceae), Diplazium montanum V.A.V.R (Athyriaceae), Stenochlaena palustris (Burm) Bedd. (Gleichnaceae), Davallia solida (Forst.) Sw. (Davalliaceae), Callistopteris apiifolia (C.Presl) Copel., Crepidomanes humile Bosch (Hymenophyllaceae), Lindsaea carvifolia Kramer, Lindsaea doryphora Kramer, Lindsaea napaea Aldrew. (Lindsaeaceae), Nephrolepis biserrata (Sw.) Schott (Nephrolepidaceae), Ceratopteris thalictroides (L.) Brongn., Haplopteris ensiformis (Sw.) E.H.Crane and Syngramma alismifolia (Pr.) J.Sm. (Pteridaceae). The habitats of Pteridophytes found were mostly terrestrial and epiphytic (34 species each), while aquatic habitat was only found to one species.

\section{ACKNOWLEDGEMENTS}

We thank the head and all staff of the Siberut National Park for the opportunity and convenience when carrying out exploration. Thanks also to the head and all staff of Herbarium Bogoriense for all the help and ease of access to the herbarium specimen during this study.

\section{REFERENCES}

Brownsey PJ, Perrie LR. 2016. Hymenophyllaceae. In: Breitwieser, I.; Heenan, P.B.; Wilton, A.D. Flora of New Zealand Pteridophytes And Lycophytes. Manaaki Whenua Press, Lincoln.

Chambers TC. 2013. A review of the genus Stenochlaena (Blechnaceae, subfamily Stenochlaenoideae). J Plant Syst 15: 13-36. DOI: 10.7751/telopea2013004.

Chandra S, Fraser-Jenkins CR, Kumari A, Srivastava A. 2008. A summary of the status of threatened pteridophytes of India. Taiwania 53 (2): 170-209. DOI: 10.6165/tai.2008.53 (2).170.

Christenhusz MJM, Chase MW. 2014. Trends and concepts in fern classification. Ann Bot. DOI: 10.1093/aob/mct299.

Conda J, Buot Jr I, Escobin R. 2017. Leaf architecture of selected Philippine Diplazium Swartz Species. Thailand Nat Hist Museum J. 11 (2): 57-75.

Creese C, Lee A, Sack L. 2011. Drivers of morphological diversity and distribution in the Hawaiian fern flora: Trait associations with size, growth form, and environment. Am J Bot 98 (6): 956-966. DOI: 10.3732/ajb.1000237.

Della AP, Falkenberg D de B. 2019. Pteridophytes as ecological indicators: an overview. Hoehnea 46 (1): 1-25. DOI: 10.1590/22368906-52/2018.

Dixit RD. 2000. Conspectus of Pteridophytic diversity in India. Indian Fern J 17: 77-91.

Dong S-Y, Zuo Z-Y, Chao Y-S, Damas K, Sule B. 2016. New species of the fern genus Lindsaea (Lindsaeaceae) from New Guinea with notes on the phylogeny of $L$. sect. Synaphlebium. PLoS ONE 11 (10): e0163686. DOI: 10.1371/journal.pone.0163686.

Ebihara A, Dubuisson JY, Iwatsuki K, Hennequin S, Ito M. 2006. A taxonomic revision of Hymenophyllaceae. Blumea J. Plant Taxon. Plant Geogr 51 (2): 221-280. DOI: 10.3767/000651906X622210.

Fraser-Jenkins, C., 2012. Rare and Threatened Pteridophytes of Asia (2) Endangered Species of India: the Higher IUCN Categories. Bull. Natl. Museum Nat Sci Ser B Bot 38 (4): 153-181.

Golan K, Rubinowska K, Gorska-Drabik E. 2013. Physiological and Biochemical Responses of Fern Nephrolepis biserrata (Sw.) Schoot. to Coccos hesperidium L. infestation. Acta Biol Cracoviensia 55: 1-6. DOI: 10.2478/abcsb-2013-0007.

Hadi S, Ziegler T, Waltert M, Hodges JK. 2009. Tree diversity and forest structure in northern Siberut, Mentawai Islands, Indonesia. Trop Ecol $50(2): 315-327$.

Hidayat A, Chickmawati T, Darnaedi D. 2011. The Fern Diversity of South East Sulawesi. IPB University, Bogor.

Holttum R.E. 1928. Spolia Mentawiensia: Pteridophyta. J Malayan Branch R Asiat Soc 6 (1): 14-23.

IUCN 2010. Guidelines for Using the IUCN Red List Categories and Criteria, version 8.1 (August 2010), prepared by the Standards and Petitions Subcommittee of the IUCN Species Survival Commission: on www. http://intranet.iucn.org/webfiles/doc/SSC/RedList/ RedListGuidelines.pdf

James E. Watkins, Jr., Catherine Cardelús, Robert K. Colwell and Robbin C. Moran. Species richness and distribution of pteridophytes along an elevational gradient in Costa Rica. Am J Bot 93 (1): 73-83.

Joshi B, Tewari S, Srivastava A, Mishra RK. 2019. Ecology and Ethnobotany of Ceratopteris thalictroides (L.) Brongn. DiscoveryPublishing House Pvt. Ltd., New Delhi, India.

Kiew R, Ummul-Nazrah A, Ong P, Imin K, Aliaa-Athirah A, Rafidah A. 2019. Distribution and conservation implications of limestone plant species in Felda Chiku Limestone. J Trop For Sci 31 (1): 19-36.

Lindsay S, Middleton D. 2015. The clarification and synonymization of two taxa of Vittaria from Peninsular Malaysia and a new combination in Haplopteris (Pteridaceae subfam. Vittarioideae). Gard Bull Sing 67 (1): 39-43.

Niinemets Ü, Portsmuth A, Tena D, Tobias M, Matesanz S, Valladares F. 2007. Do we underestimate the importance of leaf size in plant economics? Disproportional scaling of support costs within the spectrum of leaf physiognomy. Ann Bot 100 (2): 283-303. DOI: 10.1093/aob/mcm107.

Popelka O, Dančák M, Sukri RS, Metali F. 2018. Novitates Bruneienses, 10. Filmy Pteridophytes (Hymenophyllaceae) of Kuala Belalong, Brunei Darussalam. Gard Bull Sing 70 (1): 123-154. DOI: 10.26492/gbs70 (1).2018-13.

Praptosuwiryo TN. 2013. The Rare Pteridohytes of Mt. Slamet with Three Species New Record for Java. Floribunda 4 (6): 138-146. 
Richter C, Taufiq A, Hodges K, Ostner J, Schülke O. 2013. Ecology of an endemic primate species (Macaca siberu) on Siberut Island, Indonesia. SpringerPlus 2: 137. DOI: 10.1186/2193-1801-2-137.

Rugayah, A. Retnowati, F.I. Windadri dan A. Hidayat. 2004. Pengumpulan Data Taksonomi, dalam Pedoman Pengumpulan Data Keanekaragaman Hayati Flora. Pusat Penelitian Biologi, LIPI, Bogor, Indonesia. [Indonesian]

Setyawan AD. 2011. Traditionally utilization of Selaginella; field survey and literature review. Nusantara Biosci 1 (3): 146-158. DOI 10.13057/nusbiosci/n010307.

Smith AR, Pryer KM, Schuettpelz E, Korall P, Schneider H, Wolf PG. 2006. A classification for extant pteridophytes. Taxon 55 (3): 705731. DOI: $10.2307 / 25065646$.

Suparno. 2013. Kajian Kesesuaian Perairan Untuk Wisata Selancar Di Kabupaten Kepulauan Mentawai, Sumatera Barat. Prosiding Seminar Nasional Tahunan X Hasil Penelitian Perikanan dan Kelautan Tahun
2013 Jilid II: Manajemen Sumberdaya Perikanan. Fakultas Pertanian Universitas Gadjah Mada, Yogyakarta. [Indonesian]

Tsutsumi C, Chen CW, Larsson A, Hirayama Y, Kato M. 2016. Phylogeny and classification of Davalliaceae on the basis of chloroplast and nuclear markers. Taxon 65 (6): 1236-1248. DOI: $10.12705 / 656.2$.

Wardani W, Adjie B. 2017. Checklist of pteridophyte flora of Enggano Island. Floribunda 5 (6); 209-219

Whittaker DJ. 2006. A Conservation Action Plan for the Mentawai Primates. Primate Conserv 20 (20): 95-105. DOI: 10.1896/08986207.20.1.95

Wongphakdee S, Boonkerd T, Pollawatn R. 2016. Tectaria kehdingiana (Kuhn) M.G. Price (Tectariaceae), a lesser-known species from Peninsular Thailand. Songklanakarin J Sci Technol 38 (5): 575-579. DOI: $10.14456 /$ sjst-psu.2016.73. 